\title{
A mélyülő szabadkereskedelem kihívásai a déli Mediterráneumban SZIGETVÁRI TAMÁS
}

Az Európai Unió az elmúlt egy évtizedben szabadkereskedelmi egyezmények tucatjait kötötte meg. Ezek az egyezmények nem pusztán a termékkereskedelem útjában álló vámakadályok leépitését jelentik, hanem annál jóval szélesebb, a kereskedelemmel összefüggésbe kerülö más kérdéseket is szabályoznak. Az egyezmények célja, hogy versenyképessé tegyék az Európai Uniót, piacot és befektetési lehetöséget biztositsanak az európai vállalatok számára. A szomszédos régiók, így a déli Mediterráneum esetében az EU ún. Mély és Atfogó Szabadkereskedelmi Megállapodás megkötését (Deep and Comprehensive Free Trade Agreement-DCFTA) ajánlja fel, amellyel az érintett országok jogrendszerüket az európai minták alapján átalakítva lényegében az európai egységes piac részeseivé és így versenyképes gazdaságokká is válnának. Mindez az EU számára az érintett országok (első körben Marokkó és Tunézia, de hosszabb távon a többi régióbeli ország) jelentette biztonsági kockázatok csökkenését idézné elö. Bár az ún. Mély és Atfogó Szabadkereskedelmi Megállapodás megvalósitása optimális esetben valóban pozitív hatást válthat ki, és elösegítheti a déli mediterrán térség országainak világgazdasági integrációját is, egyelöre azonban a lehetőségeknél nagyobbnak látszanak a kockázatok.* Journal of Economic Literature (JEL) kódok: F13, F15, F63.

Az európai integrációban a kereskedelempolitika a kezdetek óta központi szerepet játszik. Az Európai Gazdasági Közösség a tagállamok között vámuniót hozott létre, amely szükségessé tette a harmadik országokkal kapcsolatos nemzeti kereskedelempolitikák egységesítését. Az egyre jelentősebbé váló egységes európai belső piacra való bejutás komoly vonzerővé vált minden ország számára, az EU pedig

* A tanulmány a Bolyai János kutatási ösztöndíj támogatásával készült.

Szigetvári Tamás, a Pázmány Péter Katolikus Egyetem docense, a KRTK Világgazdasági Intézet tudományos fömunkatársa. E-mail: szigetvari.tamas@btk.ppke.hu 
igyekezett termelői számára minél jobb hozzáférést biztosítani az EU-n kívüli piacokhoz. Mindebből adódóan a kereskedelempolitika az EU külső érdekérvényesítésének egyik legmeghatározóbb elemévé vált.

Az EU (mind tagállamai, mind maga az integráció) ugyan kezdetektől fogva részese a multilaterális kereskedelmi tárgyalásoknak, ennek ellenére külkapcsolataiban a speciális kereskedelmi egyezmények széles tárházát alkalmazza (Gstöhl-de Biévre, 2018, 177. o.). Ez részben a szomszédos országokkal aláírt szorosabb kétoldalú társulási és kereskedelmi egyezményeket jelentette, részben ugyanígy széles körü kereskedelmi preferenciákat nyújtó egyezményrendszer szabályozta az afrikai, a karibi és a csendes-óceáni volt gyarmatokkal fenntartott kapcsolatokat. A kétezres évektől, amikor a WTO keretében zajló multilaterális kereskedelmi liberalizáció megrekedése egyre nyilvánvalóbbá vált, az EU is mindinkább a kétoldalú szabadkereskedelmi egyezményekben látja a kereskedelmi liberalizáció továbblépési lehetőségét. Az Egyesült Államok növekvő protekcionizmusa részben tovább erösítette ezt a tendenciát, az EU a már megkötött megállapodások mellett (Dél-Korea, Kanada, Japán) számos országgal és integrációval folytat (Ausztrália, Új-Zéland, Mercosur) vagy tervez (például: India) szabadkereskedelmi tárgyalásokat. Az EU számára tehát a bilateralizmusnak és regionalizmusnak ez az újonnan népszerüvé váló formája egyáltalán nem új, az EU kereskedelempolitikája korábban is előszeretettel alkalmazta ezeket. Az utóbbi időben azonban ezen egyezmények az EU globális jelenlétének is központi elemévé váltak, amelyek nem pusztán gazdasági célokat szolgálnak, de szélesebb értelemben véve is az EU érdekérvényesítésének és értékközvetítésének hordozóivá váltak (Griller et al., 2017, 14. o.).

A szabadkereskedelmi egyezmény a kétoldalú és regionális kereskedelmi egyezmények azon típusa, amely az árukra kivetett vám- és egyéb korlátozások leépítését szabályozza. A vámunió közös külső vámokat is meghatároz, a szabadkereskedelmi megállapodás ezzel szemben csak a két fél közötti árukereskedelemre vonatkozó vámkorlátokat bontja le. Hosszú időn keresztül az EU szabadkereskedelmi egyezményei csak az ipari termékekre vonatkoztak, az erős protekcionista védelmet élvező mezőgazdasági termékekre nem. A kilencvenes évek végétől azonban itt is alapvető változások indultak. Ahogy a WTO-n belül is egyre több kereskedelemmel összefüggő terület esetében született nemzetközi szabályozás, úgy a szabadkereskedelmi egyezmények is egyre inkább túlmutattak a szimpla vámleépítésen.

Ilyen átfogó (comprehensive) típusú megállapodások megkötése az EU-val szomszédos államok esetében is napirenden van, itt azonban jelentős (többnyire egyoldalú) jogi harmonizáció is része az egyezményeknek, amelyeket ezért mély (deep) 
jelzővel is illetnek. A továbbiakban áttekintjük az EU szabadkereskedelmi egyezményeinek rendszerét és müködését, majd megvizsgáljuk, milyen lehetőségeket kínálnak az új típusú egyezmények a déli Mediterráneum országai számára, ugyanakkor ezek milyen kockázatokat rejtenek magukban.

\section{Az EU első generációs szabadkereskedelmi megállapodásai}

Az EU ún. első generációs szabadkereskedelmi (FTA) megállapodásait az EU javarészt az ezredforduló előtt kötötte, és mind tartalmukban, mind célkitüzéseikben eltérnek a mostanában kötött egyezményektől.

Az első szabadkereskedelmi megállapodások közé tartoznak az EFTA-országokkal (Norvégia, Svájc) a hetvenes években aláírt egyezmények, a kilencvenes években az Euro-med Társulási Egyezmények keretében aláírt megállapodások, de még a kétezres évek elején Mexikóval (2000) és Chilével (2003), sőt a nyugat-balkáni országokkal (2001 és 2016 között) aláírt szerződések is. A török vámunió (1995) az áruk szabad áramlását tekintve tartalmában hasonló, jellegében azonban mégis jelentősen eltérő megállapodást jelent.

Az EGK és az EFTA-tagállamok közötti szabadkereskedelmi megállapodásokat 1977-ben, Nagy-Britannia és Dánia csatlakozását követően írták alá. Ez az ipari termékekre vonatkozóan építette le az akadályokat. Az EU 1992-es létrejöttét követően valósult meg az Európai Gazdasági Tér, amely egy olyan szabadkereskedelmi övezetet alakított ki az EU és az EU-n kívül maradt EFTA-államok (jelenleg Norvégia, Izland és Liechtenstein) között, amely az áruk szabad áramlása mellett a szolgáltatások, a munkaerő és a tőke szabad áramlását is lehetővé tette. Az egyezmény értelmében az EU-n kívüli államok - annak érdekében, hogy szabadon hozzáférhessenek az EU egységes piacához - egyoldalúan átveszik és alkalmazzák az egységes piaccal kapcsolatos EU-s szabályozásokat, továbbá pénzügyi hozzájárulásukkal is segítik a társadalmi és gazdasági egyenlőtlenségek csökkentését. Az EGT-megállapodás ugyanakkor nem vonatkozik a mezőgazdasági és halászati termékekre. Bár egyes mezőgazdasági termékek esetében kedvezményes bejutást biztosítanak, és az élelmiszer-egészségügyi elöírásokat is harmonizálták, ezek a területek továbbra is kívül esnek az EGT hatáskörén. ${ }^{1}$

${ }^{1}$ Svájc nem ratifikálta az EGT-megállapodást, hanem bilaterális alapon kötött hasonló tartalmú szabadkereskedelmi egyezményt az EU-val, kiegészítve a szolgáltatás, a munkaerő és a tőke áramlására vonatkozó megállapodásokkal. 
A kilencvenes évek euro-med megállapodásai a déli Mediterráneum országaival a hetvenes években kötött egyoldalú preferenciális kereskedelmi megállapodásokat váltották fel. A társulási egyezmények keretében aláírt szabadkereskedelmi megállapodások szintén az ipari termékekre vonatkoztak, és sok esetben egyoldalú kedvezményeket biztosítottak a mediterrán államoknak. ${ }^{2}$

Az afrikai, karibi és csendes-óceáni térség (az ACP-országok) az EU kereskedelempolitikája által legrégebben preferenciális övezetként kezelt régiója. A Yaoundéi és a Loméi Konvenciók keretében az EU egyoldalú preferenciákat nyújtott az ACP-országoknak, az ipari termékek esetében aszimmetrikus vámleépítéssel. 2000ben a Cotonou-i Megállapodás új alapokra helyezte az együttmüködést, és ehhez az új megközelítéshez kapcsolhatók az új megállapodások (ez az EPA - Economic Partnership Agreement - Gazdasági Partnerségi Megállapodás).

Az ACP-országokkal kötött megállapodások ugyan szabadkereskedelmi megállapodások, de alapvetően fejlesztésorientáltak: számos aszimmetriát tartalmaznak, sok területen lehetővé téve az ACP-országoknak piacvédelmi intézkedések alkalmazását. Ugyanakkor az egyezmények célja az ACP-országok világgazdasági integrációjának elösegítése részben a regionális, részben a globális kereskedelmi kapcsolatok fejlesztésével. Bár ezen megállapodásokat is átfogóra, vagyis a szolgáltatásokat és más kereskedelemmel kapcsolatos területeket is magában foglalónak tervezték, ez végül csak a karibi országokkal kötött megállapodások esetében teljesült, a többi egyezménynél ezeket későbbi tárgyalások keretében próbálják beépíteni. A megállapodások 15-25 éves átmenettel valósítják meg a teljes liberalizációt, vagyis a hatásuk is fokozatosan érvényesül csak. Az érintett ACP-országok egy részénél a kormányzati bevételek várható csökkenése így is aggodalmat kelt (Murray-Evans, 2019). ${ }^{3}$

A nyugat-balkáni országokkal a Stabilitási és Társulási Folyamat keretében kötött az EU Stabilitási és Társulási Megállapodásokat (SAA). Ezek magukba foglalták a szabadkereskedelmi megállapodást, ugyanakkor kiterjedt harmonizációs és együttmüködési feltételrendszert is tartalmaztak, hiszen az érintett országok mindegyike a teljes jogú EU-tagságot tüzte ki célul. Montenegróval és Szerbiával már

${ }^{2}$ Ezen egyezményekkel és hatásukkal a későbbiekben részletesen is foglalkozunk, így itt nem tárgyaljuk.

${ }^{3}$ Ez főként Nyugat-Afrika esetében lehet jelentős. A Gazdasági Partnerségi Megállapodásokat regionális alapon köti meg az EU, arra biztatva az egyes régiók országait, hogy egymással is hasonló jellegü megállapodásokat kössenek. A hét regionális blokk 51 országot fed le, ebből öt afrikai, egy karibi, egy pedig csendes-óceáni. Lásd: http://www.europarl.europa.eu/RegData/etudes/BRIE/2018/625102/ EPRS_BRI(2018)625102_EN.pdf 
folynak a csatlakozási tárgyalások, Albánia és Észak-Macedónia várhatóan szintén hamarosan megkezdheti, míg Bosznia-Hercegovina és Koszovó egyelőre államiságának megszilárdításáért küzd.

A Törökországgal 1995-ben kötött vámuniós megállapodás eltér a szabadkereskedelmi megállapodásoktól, hiszen a vámunió azt jelenti, hogy Törökország egyoldalúan alkalmazza az EU harmadik országokkal szemben alkalmazott vámtételeit, emellett számos, a kereskedelemmel kapcsolatos területen (például: versenyszabályozás) harmonizálta belső jogrendszerét. A vámunió az ipari termékekre valósult meg, a mezőgazdaság, illetve a szolgáltató szektor nem része. Bár az EU-török vámunió segített a török gazdaság liberalizálásában és versenyképessé tételében, ugyanakkor a vámunió költségeinek, illetve a kereskedelempolitikai szuverenitás korlátozásának elviselését a teljes jogú tagság reménye tette elfogadhatóvá. A csatlakozási esélyek csökkenésével így Törökország egyre kevésbé érdekelt a jelenlegi vámuniós megállapodás fenntartásában (Szigetvári, 2015). Bár az egyezmény újratárgyalása, elsősorban annak kiszélesítése, átfogóvá tétele napirenden volt, azonban 2018-ban a török politikai folyamatok hatására - az EU felfüggesztette ezt a folyamatot.

Mexikó volt az első latin-amerikai állam, amely szabadkereskedelmi egyezményt kötött az EU-val. Az egyezmény 2000-ben lépett életbe, és a termékekre vonatkozó szabadkereskedelem mellett ennek már a szolgáltatáskereskedelem is a része. Chile 2002-ben írt alá az EU-val társulási megállapodást, amely hasonló elemeket tartalmazott. Ezek a megállapodások ugyan még az első generációs megállapodások közé tartoznak, de már itt is megjelennek azok az elemek (például: szolgáltatások, beruházásvédelem), amelyek a későbbiekben új elemei lesznek a szabadkereskedelmi egyezményeknek.

\section{Az új generációs szabadkereskedelmi megállapodások}

Az átalakuló nemzetközi kereskedelem szükségessé tette a kereskedelemmel kapcsolatos szabályozások átalakítását is. A WTO keretében zajló nemzetközi kereskedelemliberalizáció számos új területet vont be, a felmerülő ellentétek (elsősorban a fejlett és a fejlődő országcsoportok között) azonban lelassították a multilaterális folyamatokat. Az EU ezért bilaterális egyezmények keretében igyekezett az EU „Globális Európa” stratégiájának megfelelö, az európai vállalatok érdekeit is kiszolgáló új generációs szabadkereskedelmi (FTA) megállapodásokat kötni (SilesBrügge, 2014, 9. o.). Ezek az új megállapodások az árukereskedelem mellett már számos más területre vonatkozóan is tartalmaznak elöírásokat, így a szolgáltatásokra, a 
szellemi tulajdonjogokra, a beruházásokra, a közbeszerzésekre, az energiaszektorra, a nyersanyagokra, emellett a versenyjog, az állami tulajdonú vállalatok, a szabályozási együttmüködés is része lett ezen megállapodásoknak. Az EU sok esetben a fenntartható fejlődésre vagy az emberi jogokra vonatkozó elveket is az egyezmények részévé tesz, míg a legújabb egyezményekben a korrupció elleni harc vagy a kis- és középvállalatok kiemelt kezelése is szerepel már. Az egyezmények betarthatósága érdekében a beruházási szerződések esetében a korábbi beruházó vs. állam vitarendezési eljárások helyett az államközi vitarendezést preferálja. A 2006 után aláírt szabadkereskedelmi megállapodások már javarészt az új generációs egyezmények közé tartoznak. Ilyen a Dél-Koreával, Kolumbiával, Peruval, Közép-Amerikával és Kanadával aláírt megállapodás is. Bár az egyes szerződések tartalmukban eltérőek, az említett új területek jelentős része szerepel bennük.

A merkantilista érdekeken túl az EU saját értékeinek globális terjesztésére is igyekszik felhasználni ezeket az egyezményeket. Az EU kereskedelempolitikai stratégiája értelmében a kereskedelempolitika feladata, hogy elősegítse az EU-versenyképesség növekedését, munkahelyeket, beruházást és innovációt teremtsen. Ugyanakkor összhangban kell lennie az EU külső politikájában megfogalmazott elveivel és céljaival (például: fejlesztéspolitika, szomszédságpolitika), valamint az EU társadalmi modelljével és értékeivel is (Meissner, 2018). A fejlesztés támogatása, a munkavállalói jogok biztosítása, az emberi jogok védelme, a fenntarthatóság, a klímavédelem, de akár a demokratikus politikai berendezkedés kívánalma többnyire szintén ezen megállapodások elemei, vagyis az EU a legerősebb „fegyverével”, a kereskedelempolitikai megállapodásokkal igyekszik ezen (számára mindenképpen követendőnek tartott) értékek globális érvényesítésére. Persze felmerül a kérdés, hogy a gazdasági érdekek és az európai értékek egymásnak sokszor ellentmondó törekvése mennyiben hozható összhangba ezen egyezményekkel. E célok egyidejü érvényesítése nem egyszerű, sőt sok szempontból lehetetlen is.

Az EU a szomszédságpolitikában érintett országok esetében az átfogó szabadkereskedelmi megállapodásokhoz hasonló, de annál mélyebb kapcsolatot létrehozó ún. Mély és Átfogó Szabadkereskedelmi Megállapodás (Deep and Comprehensive Free Trade Agreement - DCFTA) megkötését javasolja. A szerződést kötő állam esetében az ipari, a mezőgazdasági és a szolgáltatásszektorra is kiterjedő szabadkereskedelmi megállapodás születik, amelyben a kereskedelemmel összefüggő területeken széles körü jogszabályi harmonizáció is szerepel. Ez az egyezménytípus gyakorlatilag az egységes piac részeseivé teszi az érintett orszá- 
gokat, hiszen itt mindig a külső fél ülteti át az EU piaci szabályozásának releváns elemeit (versenyszabályozás, szabványok, kereskedelmi elöírások stb.).

Az EU ilyen típusú megállapodást eddig a Keleti Partnerség három államával, Ukrajnával, Grúziával és Moldovával kötött. Örményország szintén tárgyalásokat folytatott egy ilyen típusú egyezményről, végül azonban az Oroszország által létrehozott Eurázsiai Gazdasági Uniót választotta. ${ }^{4}$ A Tanács 2011 decemberében hasonló megállapodásokról ajánlott tárgyalásokat a négy legfelkészültebb, a kereskedelmi kapcsolatok erősítése terén legmesszebb menő mediterrán országnak, Jordániának, Egyiptomnak, Marokkónak és Tunéziának.

Bár az ún. Mély és Átfogó Szabadkereskedelmi Megállapodások viszonylag újak, néhány hatástanulmány már igyekezett értékelni ezen megállapodások hatásait (például: Adarov-Havlik, 2016, Hoekman, 2016). Ezek alapján összességében ezen megállapodások hatása pozitívnak mondható, az egyes országok (Grúzia, Moldova Ukrajna) között azonban jelentős különbségek vannak. A legerősebben az export bővülésében érződik a pozitív hatás, az FDI esetében viszont egyelöre alig kimutatható.

Jól látható, hogy ezen országoknál a kereskedelem orientációja átalakulóban van, az EU részesedése nőtt - igaz ugyanakkor, hogy ez jelenleg csak Moldovában magas (70 százalék körüli, főként Románia és Olaszország révén), Grúzia és Ukrajna esetében továbbra is relatíve alacsony (30-35 százalék). Egyértelmű az is, hogy az EU felé fordulás mögött politikai tényezők (megromlott viszony Oroszországgal) állnak, a közvetlen gazdasági racionalitás olykor gyengébb. A kényszerűség (az orosz piac beszükülése) ugyanakkor pozitív ösztönzőket is teremt a gazdasági struktúra modernizálása és az export európai versenyképességének erősítése irányában. A szerkezeti átalakulás részben már megfigyelhető: Moldova esetében az italgyártás (bor), amely a kétezres évek elején az export 30 százalékát adta, 10 százalék alá esett, míg a gépgyártás (autóipari alkatrész) részesedése 1 százalék alatti arányról 10 százalék fölé emelkedett. Grúzia esetében az orosz bojkott szintén a borexport visszaesését eredményezte 2008 után, bár ez mára a korábbi szintre emelkedett vissza. Ukrajna esetében az átállás 2014 után gyorsult fel, és itt még inkább érzékelhető a politikai tényezők hatása. Nehezíti ugyanakkor a piacváltást, hogy a gép- és nehézipari termelés jelentős része Kelet-Ukrajnában koncentrálódik, és itt az orosz piac továbbra is prioritást élvez az EU-val szemben.

4 Oroszország - amelynek jelentős a katonai és gazdasági befolyása az országban - erőteljes nyomást gyakorolt ennek érdekében Örményországra. 
A következőkben áttekintjük az EU és a mediterrán országok közötti kereskedelmi kapcsolatokat: vagyis azt, hogyan alakultak a korábbi években, és milyen várható hatása lehet a tervezett megállapodásoknak.

\section{Az EU és a déli Mediterráneum}

A kilencvenes évektől felerősödő új regionalizmus számos fejlődő országot arra késztetett, hogy szabadkereskedelmi megállapodást kössön a legfőbb partnereinek számító fejlett országokkal. Sokan úgy gondolták, hogy ezek a kereskedelmi integrációk a gazdasági növekedés alapjai lehetnek a fejlődő országok számára: a termékei számára jobb piacra lépési lehetőséget teremtenek, a növekvő hazai verseny révén segíti a gazdaság modernizációját, ráadásul a vonzó befektetési célponttá váló gazdaságok a beáramló külföldi tőke hatására jobban tudnak integrálódni a világgazdaságba is. Ezt a nézetet az EU döntéshozói is osztották, az uralkodó narratíva értelmében a szabadkereskedelem elősegíti a gazdasági fejlődést a térségben, és ez jó az EU biztonsága szempontjából is (Langan, 2015). De már itt is jól látható a realista és az idealista megközelítés együttes jelenléte: az EU támogatja a szomszédos régiók gazdasági fejlődését, világgazdasági integrációját (idealista), de ennek elsődleges motivációja saját biztonságának szavatolása (realista).

Az EU az 1995-ben létrehozott Euro-Mediterrán Partnerség (EMP) keretében társulási megállapodásokat (Association Agreement) írt alá a déli Mediterráneum államaival. ${ }^{5}$ Az Euro-Mediterrán Partnerség három pillérre épült: politikai, gazdasági és kulturális együttmüködést is magába foglalt. A társulási megállapodások gazdasági pillére keretében szabadkereskedelmi megállapodásokat is kötöttek a térség országaival - vagyis nem az egész régióval együtt, így a tervezett euro-mediterrán szabadkereskedelmi övezet ténylegesen nem jött létre.

Ha megnézzük az azóta eltelt időszakban a déli mediterrán országok EU-val fenntartott kereskedelmi kapcsolatainak alakulását, láthatjuk, hogy a szabadkereskedelmi megállapodások nem igazán tudták beteljesíteni a hozzájuk füződő reményeket (lásd az 1. táblázatot).

5 Tunézia (1998), Marokkó (2000), Izrael (2000), Jordánia (2002), Egyiptom (2004), Algéria (2005), Libanon (2006) és a Palesztin Önkormányzat (1997, de ez átmeneti egyezmény) esetében életben van a megállapodás, Szíria esetében nem lépett életbe, míg Líbia nem írt alá társulási megállapodást. 


\section{Az Európai Unió kereskedelme a mediterrán országokkal (Med 11)*}

(2007-2018)

\begin{tabular}{cccccccc}
\hline & \multicolumn{3}{c}{ Import } & \multicolumn{2}{c}{ Export } & \multicolumn{2}{c}{ Mérleg } \\
\hline & $\begin{array}{c}\text { Millió } \\
\text { euró }\end{array}$ & $\begin{array}{c}\text { Változás } \\
\text { százalékban }\end{array}$ & $\begin{array}{c}\text { Extra-EU } \\
\text { százaléka** }\end{array}$ & $\begin{array}{c}\text { Millió } \\
\text { euró }\end{array}$ & $\begin{array}{c}\text { Változás } \\
\text { százalékban }\end{array}$ & $\begin{array}{c}\text { Extra-EU } \\
\text { százaléka }\end{array}$ & $\begin{array}{c}\text { Millió } \\
\text { euró }\end{array}$ \\
\hline 2007 & 134784 & & 9,3 & 124221 & & 10,1 & -10563 \\
2008 & 151654 & 12,5 & 9,6 & 137495 & 10,7 & 10,5 & -14157 \\
2009 & 107265 & $-29,3$ & 8,7 & 121239 & $-11,8$ & 11,1 & 13974 \\
2010 & 133333 & 24,3 & 8,7 & 150714 & 24,3 & 11,1 & 17381 \\
2011 & 132237 & $-0,8$ & 7,6 & 161916 & 7,4 & 10,4 & 29680 \\
2012 & 155499 & 17,6 & 8,6 & 175207 & 8,2 & 10,4 & 19707 \\
2013 & 146480 & $-5,8$ & 8,7 & 179427 & 2,4 & 10,3 & 32947 \\
2014 & 139396 & $-4,8$ & 8,2 & 177494 & $-1,1$ & 10,4 & 38098 \\
2015 & 133608 & $-4,2$ & 7,7 & 184987 & 4,2 & 10,3 & 51378 \\
2016 & 131942 & $-1,3$ & 7,7 & 186244 & 0,7 & 10,7 & 54302 \\
2017 & 148318 & 12,4 & 8,0 & 194194 & 4,2 & 10,3 & 45876 \\
2018 & 163113 & 10,0 & 8,2 & 187260 & $-3,6$ & 9,6 & 24147 \\
\hline
\end{tabular}

* A mediterrán országok az Eurostat esetében 11 államot jelentenek, az 5 észak-afrikai (Magreb) és 5 közel-keleti (Masrek) euro-med ország mellett Törökországot is beleérti.

** Az Extra-EU az Európai Unió tagállamainak harmadik tagországokkal fenntartott kereskedelmét jelenti, vagyis nem foglalja magában a más EU-tagállamokkal folytatott kereskedelmet.

Forrás: Eurostat.

A kétoldalú kereskedelemben a régió pozíciójának erőteljes romlása volt megfigyelhető: míg 2008-ig a déli Mediterráneum többletet könyvelhetett el a kétoldalú kereskedelemben, 2009-től kezdve egyre növekvő EU-többlet a jellemző, amelynek negatív trendje csak az utóbbi két évben fordult meg. A negatív trend egyik oka az volt, hogy 2008 után jelentősen visszaesett az EU importkereslete, ami a mediterrán behozatalt is sújtotta. Másrészről az arab tavasz és az azt követő politikai események Tunézia, Egyiptom, Líbia és Szíria exportját is jelentősen visszavetették, és a kőolaj világpiaci árának esése is kihatott a térség exportbevételeire. Árnyalja ugyanakkor a képet, hogy miközben 2013 és 2016 között az EU-ba exportált kőolaj értéke 66 milli- 
árdról 28 milliárd euróra csökkent, a teljes EU-export csak 15 milliárd euróval esett vissza, vagyis más termékek esetében növekedés volt tapasztalható. Nött az exportált élelmiszeripari termékek mennyisége (9,1-ről 11,3 milliárd euróra), míg a feldolgozóipar (70-ről 88 milliárd euróra) esetében a gép- és járműipar (28-ről 40 milliárd euróra) vált húzóágazattá. A 2016 után megindult mediterrán exportnövekedés fő húzóerejét a megugró líbiai olajkivitel jelentette (lásd a 2. táblázatot).

2. táblázat

\section{A mediterrán országok kereskedelme az EU-val}

(2007-2018)

\begin{tabular}{lrrrr}
\hline & \multicolumn{2}{c}{ Import az EU-ból } & \multicolumn{2}{c}{ Export az EU-ba } \\
\hline Algéria & 2007 & 2018 & 2007 & 2018 \\
Egyiptom & 11270 & 18911 & 20585 & 20990 \\
Izrael & 10343 & 19210 & 7039 & 8502 \\
Jordánia & 14299 & 20785 & 11343 & 13609 \\
Libanon & 2654 & 3573 & 221 & 300 \\
Líbia & 3376 & 7216 & 309 & 513 \\
Marokkó & 4228 & 4521 & 27401 & 16785 \\
Palesztin önkormányzat & 12380 & 23250 & 8115 & 16071 \\
Szíria & 46 & 243 & 14 & 18 \\
Tunézia & 3273 & 655 & 3387 & 107 \\
Törökország & 9552 & 11634 & 8991 & 10139 \\
\hline
\end{tabular}

Forrás: Eurostat.

Meg kell ugyanakkor jegyeznünk, hogy az EU-statisztikákban használt Euromed-11 országcsoport magába foglalja Törökországot is, amely messze kiemelkedik e téren a régiós országok közül, valamint Izraelt, amely szintén teljesen eltérö, nagyrészt feldolgozóipari, sokszor high-tech termékeket is magába foglaló exporttermék-szerkezettel rendelkezik. 
A szolgáltatáskereskedelem esetében - elsősorban a turizmusnak köszönhetően - ugyan többlettel rendelkezik a régió az EU viszonylatában, ez azonban messze elmarad az árukereskedelmi deficittől, és nem képes ellensúlyozni azt. Ráadásul az utóbbi években - elsősorban a mediterrán térség politikai instabilitása következtében elmaradó turizmus miatt - a szolgáltatáskereskedelem esetében is visszaesett a Mediterráneum többlete.

A mediterrán országok (Med-11) legfontosabb kereskedelmi partnere az EU, importjuk 41,6 százalékát szerezték be innen, míg exportjuk 48,6 százalékban irányult az EU-28 országaiba. Ha a teljes kereskedelmet tekintjük, az EU (44,2 százalék) messze a legfontosabb kereskedelmi partnere a régiónak, jelentősen megelőzve Kínát (9,2 százalék) vagy az Egyesült Államokat (8,4 százalék). Nagyok ugyanakkor a regionális különbségek: míg Marokkó vagy Tunézia esetében az EU a kereskedelmi forgalom 60-80 százalékát fedi le, Egyiptom esetében az arány 40 százalék, míg Jordániánál 20 százalék alatt mozog (lásd a 3. táblázatot).

3. táblázat

A Med-11 fö kereskedelmi partnerei*

\begin{tabular}{|c|c|c|c|c|c|c|c|c|}
\hline Partner & Import & $\begin{array}{l}\text { Száza- } \\
\text { lék }\end{array}$ & Partner & Export & $\begin{array}{l}\text { Száza- } \\
\text { lék }\end{array}$ & Partner & Összes & $\begin{array}{l}\text { Száza- } \\
\text { lék }\end{array}$ \\
\hline Világ & 417,2 & 100,0 & Világ & 247,5 & 100,0 & Világ & 664,6 & 100,0 \\
\hline 1. EU-28 & 173,4 & 41,6 & 1. EU-28 & 120,2 & 48,6 & 1. EU-28 & 293,6 & 44,2 \\
\hline 2. Kína & 60,0 & 13,2 & 2. USA & 28,4 & 11,5 & 2. Kína & 61,4 & 9,2 \\
\hline 3. USA & 27,2 & 6,5 & $\begin{array}{l}\text { 3. Egyesült } \\
\text { Arab Emirá- } \\
\text { tusok }\end{array}$ & 8,1 & 3,3 & 3. USA & 55,6 & 8,4 \\
\hline 4. Oroszország & 22,2 & 5,3 & 4. Irak & 7,8 & 3,2 & $\begin{array}{l}\text { 4. Orosz- } \\
\text { ország }\end{array}$ & 24,7 & 3,7 \\
\hline 5. Dél-Korea & 12,6 & 3,0 & 5. Kína & 6,4 & 2,6 & 5. India & 16,6 & 2,5 \\
\hline
\end{tabular}

* 2015-ös adatok alapján számítva.

Forrás: Eurostat.

Elég egyértelműen látszik, hogy a mediterrán, főként az észak-afrikai országok számára elsődleges jelentőségü az Európai Unióval folytatott kereskedelem, és hogy nem képesek fejlődni az uniós kapcsolatok erősítése nélkül. Az azonban 
már kevésbé egyértelmű, hogy az unió számára is valódi gazdasági érdek lenne a Mediterráneum fejlődése. Egyrészt - mint azt láthattuk - a mediterrán kereskedelem az EU külkereskedelmének elég kis hányadát teszi csak ki, másrészt a gazdasági növekedés jelenlegi üteme alapján sem mondhatjuk azt, hogy a térség különösen perspektivikusnak tünne. A mediterrán, és különösen a Magreb országoknak (Algéria, Líbia, Marokkó és Tunézia) már jelenleg is az Európai Unió az elsődleges kereskedelmi partnere, a magas exportrészesedés miatt az EU ide irányuló exportjának további növekedését csak ezen országok gazdasági növekedése révén érheti el. A merkantilista érdekeknél is fontosabb az EU szempontjából a térséghez kapcsolódó biztonsági érdek: a térség jelentette kockázatok (migrációs nyomás, társadalmi feszültségek és radikalizálódás) csökkentését leginkább ezen országok gazdasági sikere és világgazdasági integrációja segítheti elő. ${ }^{6}$

\section{Az euro-med szabadkereskedelmi megállapodások hatásai}

A következőkben azt tekintjük át, hogyan hatottak az euro-med egyezmények keretében megkötött szabadkereskedelmi egyezmények a déli mediterrán gazdaságokra, elősegítették-e a gazdasági növekedést, illetve ha nem, milyen tényezők miatt nem tudták a várt mértékben kifejteni pozitív hatásukat.

Korlátozta az egyezmények hatását, hogy a szabadkereskedelem csak az ipari termékekre vonatkozott, kimaradt a megállapodásokból a déli mediterrán országok számára központi jelentőségű agrárszféra. Igaz, itt az EU déli országainak érdekvédelme mellett (ti. hogy saját termékeik jussanak az EU belső piacára, és a külső országoknak csak kiegészítő szerep juthasson) a déli mediterrán országok részéről is ódzkodtak a rendkívül magas szubvenciókkal védett saját agrárpiacuk liberalizálástól. Az EU a legtöbb országgal kötött ugyan egyes termékek vonatkozásában az EU belső piacára való bejutást könnyítő egyezményeket, ezek hatása azonban korlátozott (mértéke pedig könnyen módosítható) volt.

Ráadásul a legtöbb déli mediterrán ország ipari termékei előtt már korábban is nyitva volt az unió piaca, hiszen a korábbi bilaterális megállapodások (a GATT GSPvel összhangban) egyoldalú piacra jutást tettek lehetővé számos termék esetében.

${ }^{6}$ Az EU 2016-os Globális Stratégiája (EUGS) kiemelten foglalkozik a szomszédos régiókkal, és a hangsúlyt az ellenálló (resilient) gazdaságok létrehozására helyezi. Az ellenálló gazdaság az EU stratégiájában a válságokkal szemben felkészült, azokat minden területen kezelni képes politikai, gazdasági és társadalmi struktúrákat és intézményeket jelenti. 
Igaz, az ún. érzékeny szektorokra, így a textil- és ruházati termékekre is speciális szabályok vonatkoztak. A textiltermékek esetében a mediterrán termelők korábban adott kvótáig exportálhattak az EU-ba, ami a GATT uruguayi fordulóján elfogadott új szabályozása miatt fokozatosan megszünt. Pedig a korábbi kvótákon alapuló Nemzetközi Textilrost Egyezmény (Multifibre Agreement - MFA) éppen az olyan kis termelőknek jelentett előnyt, mint Tunézia vagy Egyiptom, hiszen adott kvótát biztosított számukra, vagyis a versenyképesebb konkurensek (Kína, India, Pakisztán, Banglades) nem szorították ki őket.

A déli államok szempontjából tehát az euro-med megállapodások nem sok pozitív változást hoztak. Kevés áttörést jelentett a szabadkereskedelmi megállapodás azokon a területeken, ahol a mediterrán országok versenyképesek lettek volna és amelyek legfőbb exporttermékeik közé számítanak, sőt a multilaterális szabályozás változása inkább még rontotta is a lehetőségeiket. A déli államok korábban magas vámokkal védett hazai iparának viszont szembe kell néznie a megnövekedett európai konkurenciával. Annak érdekében, hogy a hazai gazdasági szereplők megerősödhessenek és fel tudjanak készülni a fokozott versenyhelyzetre, az euro-med megállapodások értelmében csak késleltetve (akár 15 év alatt) építették le a leginkább érintett, elsősorban fogyasztási cikkeket termelő szektorok esetében a vámokat. A cél az lett volna, hogy a mediterrán termelők racionalizálással és modernizációval olyan hatékonyságnövekedést tudjanak elérni, amellyel képesek lesznek felvenni a versenyt az európai termékekkel. Azonban kedvező földrajzi és logisztikai helyzetük ellenére a térség vállalkozásai nem tudtak sikeresen bekapcsolódni a multinacionális vállalatok globális értékláncaiba, önállóan pedig alig váltak sikeressé. Bár néhány pozitív példát találhatunk Tunézia, Marokkó vagy akár Egyiptom esetében is, ezek azonban inkább kivételek, nem általánosak (Del Prete et al., 2016, 265. o.).

Mint az említett tényező is mutatja, a szabadkereskedelem és az EU-val egyre szorosabbá váló gazdasági integráció nem igazán tette vonzóvá a térséget a külfölditőke-befektetések számára. Az a hatás, ami a kelet-közép-európai országok esetében a kilencvenes évektől a kétezres évek elejéig lehetővé tette a külföldi tőkére épített modernizációt, a déli mediterrán térség kapcsán elmaradt.

A tőke beáramlását akadályozta többek között az is, hogy a szabadkereskedelmi megállapodást az EU bilaterálisan kötötte az egyes mediterrán államokkal, vagyis valójában nem jött létre az egész Mediterráneumra kiterjedő szabadkereskedelem. A részt vevő déli államok között hiányzó megállapodások megnehezítik a való- 
di szabadkereskedelmet, így az ún. „hub-and-spoke” (kerékagy és küllők) hatás következtében az EU sokkal kedvezőbb befektetési célpont maradt, mint az egyes partnerországok (Ülgen, 2011, 19. o.). A 2004-es agadíri megállapodás keretében ugyan Marokkó, Tunézia, Egyiptom és Jordánia megkezdte az egymással szembeni akadályok lebontását, ez a folyamat azonban meglehetősen nehezen halad, és a származási országok kumulálási rendszerének ${ }^{8}$ bonyolultsága is nehezítő tényező. A régión belüli kereskedelem máig meglehetösen alacsony, a régió összkereskedelmének mindössze 2,2 százalékát teszi ki. A meglévő kapcsolatok is elsősorban az egyes szubrégiókon belül jellemzők, tehát a Magreb és Masrek, vagyis a Mediterráneum nyugati és keleti országai közötti kereskedelem még az előbbinél is kisebb.

A privát tőke mellett (vagy inkább helyett) az EU fejlesztési segély nyújtásával igyekezett elősegíteni az euro-med partnerországok gazdasági fejlődését. A különböző intézményi keretek között 1979 és 2013 között összesen 16 milliárd euró fejlesztési segélyben részesültek a déli mediterrán országok részben a különbözö uniós pénzügyi eszközökből, részben kétoldalú támogatásokból (Ayadi és Gadi, 2013). 1995 után egyértelműen megnőtt a térségnek allokált források aránya, ami egyértelmúen mutatja az EU megnövekedett érdeklődését is, de az egyes országok közötti eltérések e téren is jól kirajzolódnak. Szintén jól láthatók voltak az egyes EUtagállamok eltérő prioritásai. Az EU déli országai (spanyolok, olaszok, de részben a franciák, görögök és portugálok) alapvetően a „protekcionizmus + nagyobb támogatások" típusú megoldásban voltak érdekeltek, hiszen nem érdekük a konkurens déli mezőgazdasági termékek beengedése, maguk is kevésbé exportálnak ezekbe az országokba, ugyanakkor fontos számukra, hogy az EU is támogassa azokat a beruházásokat (például: infrastrukturális, környezetvédelmi), ami számukra is hasznos. Az északi országok ugyanakkor hagyományosan a szabadkereskedelmet támogatják ipari (és agrár-) termékeik exportja miatt, de kevésbé érdekeltek a jelentős pénzügyi támogatás nyújtásában. A két terület (kereskedelem nyitottsága és támogatások nagysága) tekintetében tehát éppen ellentétesek az EU-n belüli érdekviszonyok (Kourtelis, 2015).

A mediterrán országok közül talán Tunézia gazdasága volt a legfelkészültebb a szabadkereskedelmi megállapodásra. Ennek ellenére a megállapodás következ-

${ }^{7}$ A „,hub and spoke” hatás értelmében az EU mint központ (hub) és az egyes déli államok (spoke) között sokkal egyszerübb és így intenzívebb a kapcsolat, mint az egyes déli államok között.

${ }^{8}$ A szabadkereskedelmi egyezmények többnyire két ország között érvényesek. A kumuláció azt teszi lehetővé, hogy ezen egyezmények hatását összevonják, vagyis az egyes országokra vonatkozó kedvezmények azokra a termékekre is érvényesek legyenek, amelyek több hasonló egyezménnyel rendelkező országból származó részt tartalmaznak. 
ményei itt sem egyértelmúen pozitívak, ami a 2010 végén az arab tavasz kiindulópontjának számító tiltakozásokban is kifejeződött. A sikertelenség részben Tunézia gazdaságpolitikai hibáinak tudható be, igaz a nemzetközi szervezetek és az EU is támogatta a szigorú fiskális és árfolyam-politika túlzott erőltetését a versenyképesség és a gazdaság növekedési potenciáljának erősítése helyett. Megemlítendő még az adóbehajtás gyengesége mind a tőke-, mind a bérjövedelmek esetében, a külső és belső tőkebefektetéseket is elősegítő közberuházási projektek elhanyagolása, egy átlátható versenypolitika kialakítása és a külkereskedelemmel kapcsolatos bonyolult ügyintézés fennmaradása (Chemingui-Bchir, 2012, 113. o.).

Még további okra is visszavezethető az, hogy a gazdasági együttmüködés szabadkereskedelemre építő európai modellje nem vált sikeressé a Mediterráneummal kapcsolatban. Ebben a Mediterráneum politikai instabilitása, az EU belső válságok miatti gyengébb elköteleződése, a szolgáltatásliberalizáció elmaradása, a szabályozás harmonizálásának hiánya is közrejátszott (Borrell-Porta, 2012, 15. o.) Éppen ez utóbbi tényezők miatt merül fel, hogy az egyezmények megújításával, elmélyítésével esetleg jobban érvényesülhetnének a szabadkereskedelem pozitív hatásai.

\section{A DCFTA és a déli mediterrán országok}

Az arab tavasz eseményei is hozzájárultak ahhoz, hogy az Európai Bizottság az Európai Szomszédságpolitika (ENP) megújítását tűzte ki célul. A gazdasági kapcsolatok intenzívebbé tételére egyik felmerülő lehetőségként a jelenleginél mélyebb és átfogóbb szabadkereskedelmi megállapodások adódnak (a DCFTA-k, az ún. Mély és Átfogó Szabadkereskedelmi Megállapodások). Az EU-val ilyen típusú szerződést kötő állam esetében az ipari szabadkereskedelmen jóval túlmutató, a mezőgazdaságra és a szolgáltatásszektorra is kiterjedő megállapodás születik, ami széles körü jogszabályi harmonizációt is jelent - természetesen a külső fél ülteti át az EU közös piaci szabályozásainak releváns elemeit (versenyszabályozás, szabványok, kereskedelmi előírások stb.). Ezek hatásaként az adott gazdaság a korábbi szabadkereskedelmi megállapodásoknál jóval szorosabban integrálódik az egységes gazdasági térbe. Az EU 2014-ben ilyen típusú megállapodást kötött a Keleti Partnerség három államával, Ukrajnával, Grúziával és Moldovával.

Mint azt már a korábbiakban is említettük, ezen szerződések hatékonyságával kapcsolatban nehéz állást foglalni, hiszen a már megkötött egyezmények tapasztalatai egyelőre korlátozottan állnak rendelkezésre, és az eltérő körülmények és környe- 
zet amúgy is megnehezítik az összehasonlíthatóságot. Mindenképpen elöremutatók lehetnek ezek a megállapodások abból a szempontból, hogy jóval erőteljesebb modernizációs kényszert jelentenek a részt vevő országok számára, és a jogi harmonizáció erősítheti tőkevonzó képességüket, illetve lehetőségeiket a nemzetközi termelési hálózatokba történő bekapcsolódásra. Kérdés ugyanakkor, hogy a szuverenitás részleges feladásával is járó egyoldalú harmonizáció valóban szükséges-e. Az EU a nem szomszédos államokkal (például: Kanadával) is olyan új típusú szabadkereskedelmi megállapodásokat köt, amelyek a szolgáltatásokat is magukba foglalják, ugyanakkor a harmonizációt az acquis szabályainak kötelező átvétele nélkül teszi lehetővé (Hoekman, 2016, 13. o.). Emellett az ún. Mély és Átfogó Szabadkereskedelmi Megállapodások jelentősen növelik a differenciálást - ez ugyan az utóbbi időszakban az európai szomszédságpolitikának egyértelmű törekvésévé vált, ugyanakkor ennek a hatásai is kérdésesek: vajon képes-e ez a differenciálás húzóerôt jelenteni a többi ország számára. Ráadásul, míg a keleti partnerországok esetében megkötött ún. Mély és Átfogó Szabadkereskedelmi Megállapodással járó kiterjedt harmonizációs kötelezettség költségeinek viselése mögött a jövőbeli teljes jogú tagság reménye állhat (lévén európai országokról van szó), a délieknél erről nincs szó.

Ennek ellenére a Tanács 2011 decemberében hasonló megállapodásokról ajánlott tárgyalásokat a négy legfelkészültebb, a kereskedelmi kapcsolatok erősítése terén legmesszebb menő déli mediterrán országnak, Marokkónak, Tunéziának, Egyiptomnak és Jordániának. Az ajánlat jelentős részben az arab tavasz „sokkjára” adott válaszlépésként is értelmezhető (van der Loo, 2015, 1. o.): míg Tunézia és Egyiptom közvetlenül is érintett volt a térséget megrázó politikai változásokban, az alkotmányos monarchiaként stabilabb politikai legitimációval rendelkező Marokkót és Jordániát elkerülte a „forradalom”.

Az Európai Bizottság számára készített előzetes hatástanulmányok, amelyek 2013-ban és 2014-ben készültek el (Ecorys, 2013a, b, Ecorys, 2014a, b), részletesen megvizsgálták, hogy egy ilyen megállapodásnak milyen várható gazdasági, társadalmi és környezeti hatása lenne az érintett országokban (lásd a 4. táblázatot). A vizsgálati modell feltételezésében például a mezőgazdasági termékek vámjai az EUban a tunéziai termékeket illetően 95 százalékkal, Tunéziában az EU-s termékekre 80 százalékkal csökkennek, a nem vámjellegü akadályok esetében szektoronként becsüli a várható hatásokat, illetve figyelembe veszi a szabályozási harmonizáció továbbgyűrüzésének hatását is. A hatástanulmány mind a négy országot alkalmasnak találta ilyen típusú egyezmény megkötésére, és mind a négy esetében - a meglévő kockázatokat is megemlítve - összességében pozitív kimenetelünek értékelte azokat. 


\begin{tabular}{|c|c|c|c|c|}
\hline & Tunézia & Marokkó & Egyiptom & Jordánia \\
\hline Nemzeti jövedelem növekedése (millió euró) & +2498 & +1300 & +3374 & +442 \\
\hline GDP (százalékos növekedés) & $+7,4$ & $+1,6$ & $+1,8$ & $+2,1$ \\
\hline Bérek (százalékos növekedés) & $+10,0$ & $+1,7$ & 0 & $+3,0$ \\
\hline Export (százalékos növekedés) & $+20,4$ & $+15,3$ & $+26,7$ & $+5,3$ \\
\hline Import (százalékos növekedés) & $+17,7$ & $+8,4$ & $+24,8$ & $+4,8$ \\
\hline
\end{tabular}

Forrás: Ecorys [2013a, b, 2014a,b].

A négy országot összehasonlítva kirajzolódik, hogy a legjelentősebb várható gazdasági elöny Tunéziában realizálódhat, hosszú távon a GDP 7 százalék fölötti mértékét kitevő mértékben. Érdekes módon a másik, az EU-val szoros kapcsolatban lévő gazdaság, Marokkó esetében a várható haszon ettől lényegesen elmarad. A hatástanulmányok részletesen vizsgálják a megállapodások szektoriális hatásait is, megállapítva, hogy mely szektorok nyerhetnek és melyek veszthetnek a megállapodások következtében. Bár az egyes országokban eltérnek a hatások, általánosságban kijelenthető, hogy az élelmiszeripar általában vesztese a folyamatnak, ugyanakkor a gyümölcs- és zöldségszektor vagy a növényi olajipar Tunézia és Marokkó esetében is komoly nyertese lenne a megállapodásnak. Míg a textilipar vagy a bőripar általánosságban rosszul járna, a gépgyártás és néhány feldolgozóipari tevékenység számára erősen pozitív hatást fejtene ki a megállapodás.

A várható társadalmi hatások is sokrétűek: míg általánosságban itt is megállapítható, hogy a GDP-re és a nemzeti jövedelemre gyakorolt pozitív hatás a bérek emelkedését is magával vonja, Egyiptom esetében a hatástanulmány is azt prognosztizálja, hogy a növekedés csak a magasabb és középjövedelműek számára várható, az alacsonyabb bérűeknél a hatása várhatóan inkább negatív lesz.

AZ EU mind a négy országnak felajánlotta ugyan a megállapodást, közülük azonban csak Marokkó és Tunézia jelezte érdeklődését, ez érthető, hiszen ezen országok gazdasága és kereskedelme is jóval szorosabban kapcsolódik az EU-hoz, így számukra az egységes európai piac és a szorosabb integrálódás mindenképpen vonzó lehetőségnek tünik. 
Marokkóval 2013-ban megkezdődtek a tárgyalások. Néhány forduló után azonban a kereskedelemmel összefüggő politikai viták ${ }^{9}$ miatt elakadtak, és a kétoldalú kapcsolatok komolyan megromlottak (van der Loo, 2018). A kialakult helyzet 2019re normalizálódott, és az EU jelenleg a kétoldalú tárgyalások újraindításán dolgozik. Tunéziával 2016-ban kezdődtek meg a tárgyalások, de mindkét oldalon erős ellenállás érezhető. Az EU-ban a déli agrártermelők nem szeretnék szabadon beengedni a konkurens termékeket, míg Tunéziában a megállapodás negatív gazdasági és társadalmi hatásai keltenek félelmet (Rudolf-Werenfels, 2018).

A szerződésekkel együtt járó erőteljes jog- és szabályozási harmonizáció költségei igen magasak, amiket csak egy versenyképessé váló, az európai piaci jelenlétet maximálisan kiaknázni képes gazdaság többletbevételei tudnák kompenzálni. A déli mediterrán országok esetében - a korábbi tapasztalatok alapján is - a szabadkereskedelem erőteljes dinamizáló hatása erősen megkérdőjelezhető, ez kérdésessé teszi azt, hogy a kereskedelem elmélyítése mennyiben járható útja az EU és a déli mediterrán országok közötti kapcsolatrendszer fejlesztésének.

\section{Összegzés}

A globális gazdasági környezet és a nemzetközi kereskedelempolitika átalakulása a bilaterális kereskedelmi egyezmények növekvő népszerüségét és fontosságuk növekedését hozta magával. Mivel a WTO keretében zajló multilaterális egyeztetési folyamatok erősen akadoznak, az Európai Unió az elmúlt egy évtizedben szabadkereskedelmi egyezmények tucatjait kötötte meg. Ezek az egyezmények az árukereskedelmen túl a kereskedelemmel összefüggő egyéb területeket is szabályozzák, részben harmonizálják. A szomszédos régiók esetében azonban az egyezmények ennél is tovább mennek. A megállapodások az erőteljes egyoldalú jogharmonizáció megvalósításával arra törekszenek, hogy az érintett országok - tényleges csatlakozás nélkül is - az európai egységes piac részeseivé váljanak, és jogrendszerüket az európai minták alapján átalakítva versenyképes, növekvő gazdaságokat hozzanak létre.

A gazdasági együttmüködés szabadkereskedelemre építő európai modelljét az EU a kilencvenes évek óta a déli mediterrán országok irányába is alkalmazta, ez azonban nem vált egyértelmüen sikeressé. Bár ez több tényezőre is visszavezethető, az euro-med egyezmények korlátozottsága, az agrár- és szolgáltatáskereskedelem li-

92015 decemberében az Európai Bíróság a Marokkó által megszállt Nyugat-Szaharából behozott termékek esetében nem tartotta érvényesnek a kétoldalú megállapodásokat, vagyis megkérdőjelezte Marokkó fennhatóságát a terület felett. 
beralizációjának hiánya, a térség bürokratikus és a versenyt akadályozó szabályozási környezete is közrejátszottak ebben. Az EU ezért jelenleg a szabadkereskedelem elmélyítésében látja a kapcsolatok továbbfejlesztésének útját. Bár ez optimális esetben valóban pozitív hatást válthat ki, és elősegítheti a térség országainak világgazdasági integrációját is, egyelöre azonban a kockázatok nagyobbnak látszanak a lehetőségeknél. A megállapodások rövid távon mindenképpen komoly költségekkel járnak, és ezeket az EU csak korlátozottan tudja átvállalni. Tényleges csatlakozási esélyek hiányában az egyoldalú jogharmonizáció aránytalan terheket és felesleges költségeket jelent a déli mediterrán országok számára.

Mindezek alapján komolyan fennáll a veszélye annak, hogy a megállapodások erőltetése a déli mediterrán országok esetében kontraproduktív eredménnyel jár, inkább rontja, mint javítja az érintett országok helyzetét, és ez az EU számára egyre fontosabbá váló biztonság szempontjából is negatív hatású.

\section{Felhasznált irodalom}

Adarov, A. - Havlik, P. [2016]: Benefits and Costs of DCFTA: Evaluation of the Impact on Georgia, Moldova and Ukraine. Joint Working Paper by the Vienna Institute for International Economic Studies (wiiw) and Bertelsmann Stiftung.

Ayadi, R. - Gadi, S. [2013]: The Euro-Mediterranean Partnership and Development Assistance: Past Trends and Future Scenarios. MEDPRO Technical Report, No. 32., március.

Borrell-Porta, M. [2012]: The importance of institution-building in free trade agreements. In: Joan Costa-Font (szerk.): Europe and the Mediterranean Economy. Routledge, Abingdon-New York, 3-23. o.

Chemingui, M. A. - Bchir, H. [2012]: Have the promises used to sell the Euro-Mediterranean partnership come true? Illustration from the Tunisian experience. In: Joan Costa-Font (szerk.): Europe and the Mediterranean Economy. Routledge, Abingdon-New York, 93-115. o.

Dadush, U. - Myachenkova, Y. [2018]: Assessing the European Union's North Africa trade agreements. Policy Contribution, No. 22., Bruegel, november.

Del Prete, D. - Giovannetti, G. - Marvasi, E. [2016]: Small and Medium Enterprises' Competitiveness through Global Value Chains. IEMed Mediterranean Yearbook 2016, European Institute of the Mediterranean, Barcelona, 263-268. o.

Ecorys [2013a]: Trade Sustainability Impact Assessment in support of negotiations of a DCFTA between the EU and Tunisia. Final Report. Rotterdam, 25 November. Letölthetö: https://trade. ec.europa.eu/doclib/docs/2013/november/tradoc_151923.pdf

Ecorys [2013b]: Trade Sustainability Impact Assessment in support of negotiations of a DCFTA between the EU and Morocco. Final Report. Rotterdam, 25 November. Letölthetö: https://trade. ec.europa.eu/doclib/docs/2013/november/tradoc_151926.pdf

Ecorys [2014a]: Trade Sustainability Impact Assessment in support of negotiations of a DCFTA between the EU and Jordan. Final Report. Rotterdam, 30 September. Letölthetö: https://trade. ec.europa.eu/doclib/docs/2013/november/tradoc_153141.pdf 
Ecorys [2014b]: Trade Sustainability Impact Assessment in support of negotiations of a DCFTA between the EU and Egypt. Final Report. Rotterdam, 3 November. Letölthető: https://trade. ec.europa.eu/doclib/docs/2013/november/tradoc_153139.pdf

European Commission [2018]: Individual reports and info sheets on implementation of EU Free Trade Agreements. Brussels, SWD (218) 454 final. Letölthető: http://trade.ec.europa.eu/doclib/ docs/2018/october/tradoc_157473.PDF

Griller, S. et al. [2017]: Mega-Regional Trade Agreements: New Orientations for EU External Relations? In: Griller, S. - Obwexer, W. - Vranes, E. [2017]: Mega-Regional Trade Agreements: CETA, TTIP, and TiSA. New Orientations for EU External Economic Relations. Oxford University Press.

Gstöhl, S. - de Biévre, D. [2018]: The Trade Policy of the European Union. Palgrave Macmillan.

Hoekman, B. [2016]: Deep and Comprehensive Free Trade Agreements. EIU Working Papers, RSCAS 2016/29, European University Institute.

Kourtelis, C. [2015]: The Political Economy of Euro-Mediterranean Relations: European Neighbourhood Policy in North Africa. Palgrave Macmillan.

Langan, M. [2015]: The moral economy of EU relations with North African states: DCFTAs under the European. Third World Quarterly, Vol. 36., No. 10., 1827-1844. o.

Meissner, K. L. [2018]: Commercial Realism and EU Trade Policy. Routhledge, London-New York.

Murray-Evans, P. [2019]: Power in North South Negotiations. Making the European Union's Economic Partnership Agreements. Routledge, London-New York.

Rudolf, B. - Werenfels, I. [2018]: EU-Tunisia DCFTA: Good Intentions Not Enough. Shift Needed from Deep to Deliberate, Comprehensive to Coherent and from Free to Fair Trade. SWP Comment, 2018/C 49, November.

Siles-Brügge, G. [2014]: Constructing European Union Trade Policy. A Global Idea of Europe. Palgrave-Macmillan.

Szigetvári T. [2015]: EU-török vámunió: működik-e a „török modell”? Külgazdaság, 59. évf., 7-8. sz., 99-115. o.

Ülgen, S. [2011]: A Faster, Better Route to Economic Integration Across the Mediterranean. EDAM Discussion Paper Series, No. 3. Centre for Economics and Foreign Policy studies (EDAM), Istanbul.

van der Loo, G. [2015]: Enhancing the Prospects of the EU's Deep and Comprehensive Free Trade Areas in the Mediterranean: Lessons from the Eastern Partnership, CEPS Commentary, június 24.

van der Loo, G. [2018]: The Dilemma of the EU's Future Trade Relations with Western Sahara: Caught between strategic interests and international law? CEPS Policy Brief, április 20. 